九州大学学術情報リポジトリ

Kyushu University Institutional Repository

\title{
A SHORT HISTORY OF THE HIKOSAN BIOLOGICAL LABORATORY
}

Hirashima, Yoshihiro

Chujo, Michitaka

https://doi.org/10.5109/2491

出版情報: ESAKIA. 25，pp.1-4，1987-01-31. Entomological Laboratory，Faculty of Agriculture， Kyushu University

バージョン :

権利関係 : 


\title{
A SHORT HISTORY OF THE HIKOSAN BIOLOGICAL LABORATORY
}

\author{
Y. Hirashima and M. T. ChÛJô \\ Hikosan Biological Laboratory, Faculty of Agriculture, \\ Kyushu University, Hikosan, Fukuoka 824-07, Japan
}

The Hikosan Biological Laboratory (HBL) is one of the satellite research institutions of Kyushu University and is located on the middle slope $(650-700 \mathrm{~m})$ of Mt. Hikosan (1,200 m). Founded in 1936, on October 20 of that year to be exact, this institution is celebrating its 50th anniversary in 1986.

HBL was donated to Kyushu University by the good faith of Baron Nobumaro Takachiho (18651950) and a businessman named Mr. Etsuji Nakayama (1883-1951). This kind of beginning for an institution is unusual for Japanese universities.

Baron Takachiho was born in Kyoto and educated in Tokyo. He moved to Kyushu in 1883 and lived in Hikosan, a small town located midway up Mt. Hikosan which was at that time famous for Shugendo, a kind of religious pursuit. The Hikosan Jinja (later, Hikosan Jingu), a shrine for both the Shinto and Buddhist religions, is the symbol of this mountain which translates as "a mountain of faith".

Baron Takachiho was the chief priest of Hikosan Jinja. He was also very fond of insects and a true naturalist. He soon had a fine collection of insects and had observed the habits and behaviour of many different species. Mt. Hikosan was then a virgin place for the study of insects, and virtually the entire mountain was Baron Takachiho's front garden.

His enthusiasm for insects led to the establishment in 1900 of the Takachiho Entomological Laboratory, which was changed to the Kyushu Entomological Laboratory in 1903.

Dr. Inokichi Kuwana, who was a famous economic entomologist in Japan in the first quarter of this century, was a close collaborator of Baron Takachiho's at that time. A graduate of Harvard University, Dr. Kuwana was a young and vigorous entomologist who had just come back to Japan from the USA.

After 50 years of entomological activity, Baron Takachiho wanted to establish a museum or institution to house his insect collection and related literature and to donate this to Kyushu University. He owned a vast area of land in the town of Hikosan so that he was able to cede a part of his estate to Kyushu University as a site for the new institution. Today the $320 \mathrm{~m}^{2}$ facilities of HBL stand on a portion of the $33,000 \mathrm{~m}^{2}$ on which long ago the magnificent residence of an ancestor of Baron Takachiho stood. This ancestor was the president of several thousand priests who lived in so-called Bo-houses scattered on the slope of the mountain. These Bo-houses were said to number about 3,800 at one time. Thus, the Hikosan Biological Laboratory occupies the most beautiful and renowned location on Mt. Hikosan today.

Mr. Etsuji Nakayama was a man of good faith who owned a steelworks in Osaka City in about 1930. He was born in a small village in Fukuoka Prefecture, Kyushu, not very far from Mt. Hikosan. 


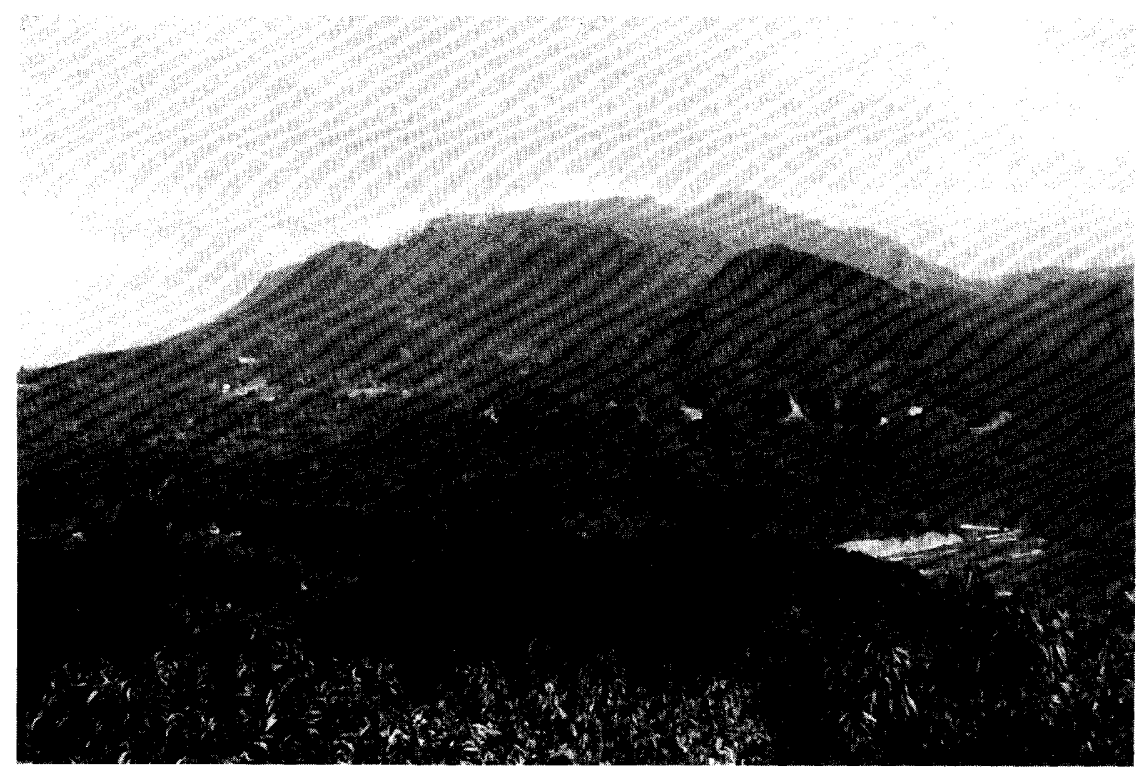

Mt. Hikosan $(1,200 \mathrm{~m})$ (on the back).

Because of his love for his home, Mr. Nakayama supported Baron Takachiho's idea of establishing a branch institution of Kyushu University in the town of Hikosan. In 1936 he therefore donated to the University the amount of $¥ 10,136.44$ which covered the construction of HBL. Thus, the Hikosan Biological Laboratory was founded through the cooperation and benevolence of Baron Takachiho and Mr. Nakayama.

This institution is used primarily for the studies of insects, or entomology, and the mountain fauna of birds, mammals and other animals. The flora of Mt. Hikosan is also studied intensively by the staff of HBL, although no specialist in plant taxonomy is attached to the laboratory.

The first director of HBL was Dr. Teiso Esaki, then Professor of Entomology at Kyushu University, who was a good friend of Baron Takachiho. He held the directorship until his death in 1957. Director Esaki appointed the first three scientists to HBL, Mr. Hiroshi Hori (Research Associate in Entomology, Kyushu University), Dr. Keizo Yasumatsu (Associate Entomologist at Kyushu University) and Baron Takachiho. Among them, only Dr. Yasumatsu was a full-time research worker for HBL, moving to Hikosan from Fukuoka City and living there from December 1936.

After 3 years of service, Dr. Yasumatsu was appointed Research Associate in Entomology (equivalent to Assistant Professor of Entomology) and left HBL for the Hakozaki Campus in Fukuoka City in 1939. During his period at HBL he engaged in biological studies of insects as well as of the systematics of bees and wasps, or Hymenoptera. Dr. Yasumatsu's papers on insect biological studies conducted on Mt. Hikosan were so interesting that they soon became the object of attention of entomologists in Japan. Dr. Yasumatsu was promoted to Associate Professor of Entomology in 1942 and to Professor in 1958, and at the same time was appointed Director of HBL. He held these concurrent responsibilities until his retirement from Kyushu University in 1971.

Mr. Koroku Abe, an ornithologist, worked for HBL as a non-regular staff member for 3 years 


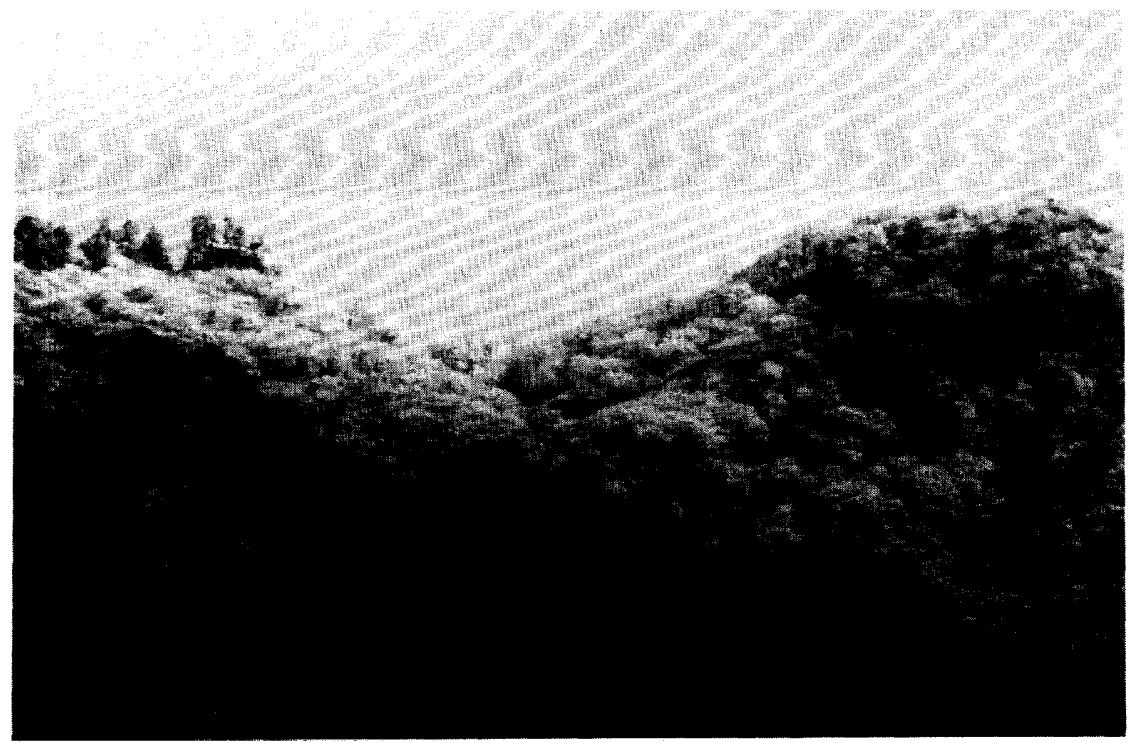

The summit of Mt. Hikosan, a winter scenery.

from March 1943. He is one of the founders of the Fukuoka Ornithological Society.

Dr. Shushiro Ito was appointed as Entomologist-in-charge for HBL in November 1944. He was the second of the full-time research scientists to live in Hikosan. A graduate of Kyushu University (under Prof. T. Esaki) and a specialist on flies of the family Trypetidae, he retired from HBL in July 1947 and thereafter moved to Osaka Prefectural University.

Dr. Akinobu Habu, a specialist in the Coleoptera, was appointed as Entomologist-in-charge at HBL in May 1948. He worked for this institution for 5 years until May 1953 when he left for the Agricultural Research Institute in Nishigahara, Tokyo. During his 5 years of service, Dr. Habu developed a fine collection of beetles for HBL and published many papers on the taxonomy of the Carabidae including interesting and rare species he had found on Mt. Hikosan.

Dr. Hiroshi Kuroko, a specialist of Microlepidoptera, was then appointed as Entomologist-incharge for HBL in August 1953 and remained for 12 years until March 1965 when he left for Osaka Prefectural University. Dr. Kuroko was appointed Associate Professor in Entomology at Kyushu University in 1962.

In 1960 the journal of entomology ESAKIA was founded by Prof. Yasumatsu, then the director of HBL. This journal, which was named after Prof. T. Esaki, was published irregularly for the first 10 issues, having the subtitle "Occasional Papers of the Hikosan Biological Laboratory in Entomology". This was changed to "Kyushu University Publications in Entomology" from No. 11 (1978) when Prof. Y. Hirashima, Chairman of the Entomological Laboratory of the University became the editor-in-chief. Since then, ESAKIA has been published jointly with the Entomological Laboratory of the University on a regular basis (once a year). Prof. Hirashima has held the concurrent post of director of HBL since 1975.

One of the most outstanding contributions made by Dr. Kuroko was the discovery of the egg and the first instar larva of Climaciella magna (Miyake), one of the largest species of Mantispidae (Neuroptera) in the world. Although the host of this magnificent insect is not yet known, the adults 
are common on the campus of HBL every autumn and are collected as they gather around lights. The immature stage of Climaciella magna was described by Kuroko in 1961 (Esakia, No. 3, pp. 25-32, 5 pls.).

Dr. Shinsaku Kimoto was appointed Research Entomologist at HBL in August 1962, and was promoted to Entomologist-in-charge in 1965 after Dr. Kuroko had left. Dr. Kimoto worked for about 7 years until he left for Kurume University in March 1969. He contributed to the systematics of the Chrysomelidae and was a close research associate of Dr. J. L. Gressitt, the chairman of the Department of Entomology, Bishop Museum, Honolulu, Hawaii. Dr. Kimoto was also interested in the zoogeography of insects, and published several papers on this subject.

Mr. Michitaka Chûjô, Research Associate in Entomology at the Entomological Laboratory of Kyushu University, was transferred to HBL in April 1969 and appointed as Entomologist-in-charge. A specialist of the Coleoptera, especially the Tenebrionidae, Mr. Châjô has devoted himself to the laboratory for the past 17 years. He was promoted to Associate Professor of Entomology of Kyushu University in December 1976.

Other entomologists who have worked for HBL are :

Dr. Kenkichi Kanmiya, 1969-1970. A specialist of the Chloropidae and now a lecturer of biology at Kurume University, he is also known for his study of acoustic communication in insects.

Mr. Kazuo Nosato, for 2 months only in 1970. He is now an Associate Professor of Entomology at Kochi University.

Mr. Nariaki Yoshida, 1970-1971. He is now Entomologist-in-charge at the Entomological Laboratory, Hokkaido Branch of The Forestry and Forest Products Research Institute, Sapporo.

The present staff members are :

Dr. Y. Hirashima, Director; Professor of Entomology.

Mr. M. T. Chûjô, Entomologist-in-charge ; Associate Professor of Entomology.

Mr. K. Takeno, Technician and Research Associate.

Mr. K. Teshima, Technical Assistant.

The Hikosan Biological Laboratory is open to biologists of any nation. The institution is provided with 2 bedrooms for visitors who are numerous every year. 


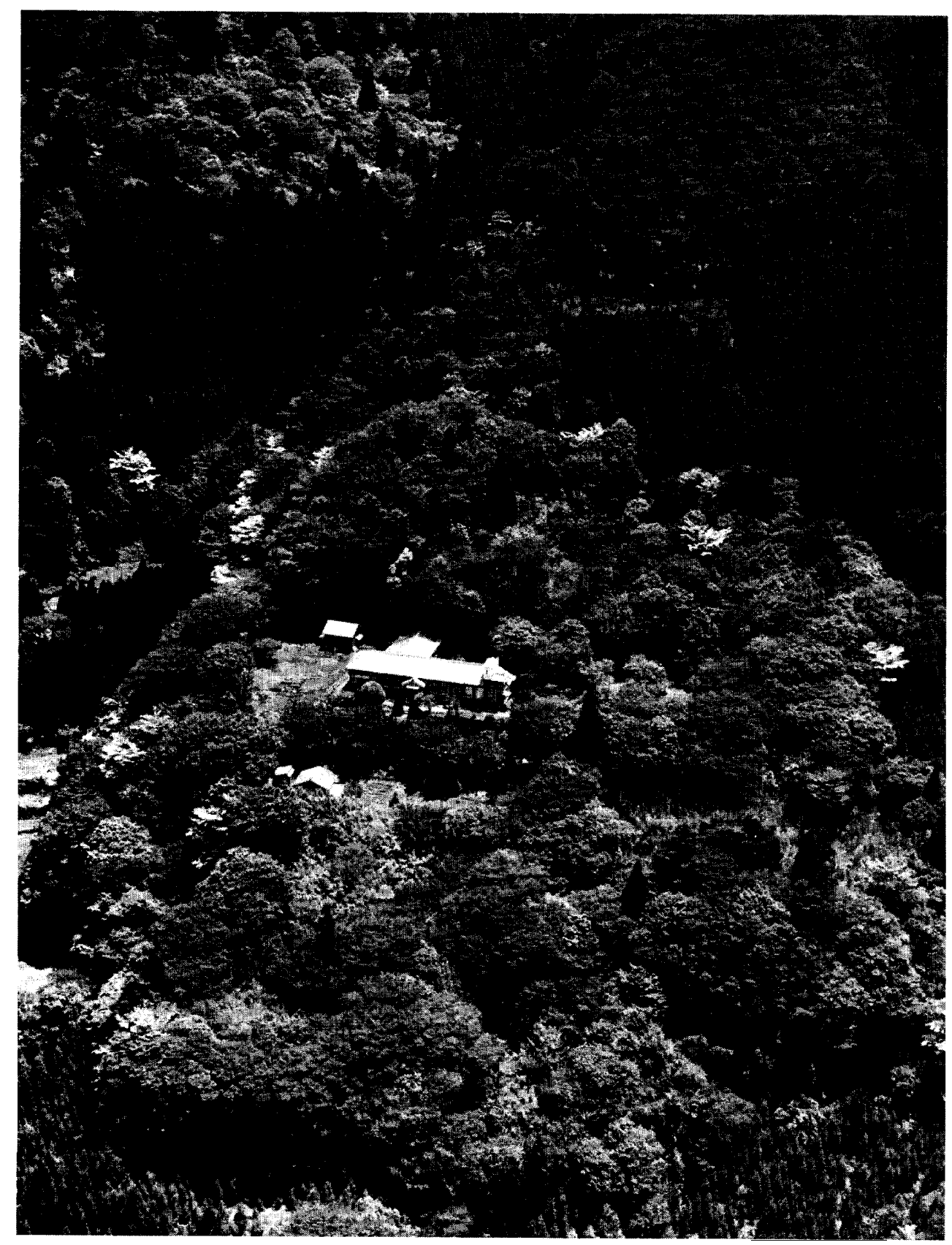

Aerial photograph of the Hikosan Biological Laboratory.

(By the courtesy of the Yomiuri Press). 